\title{
READING TOURS INTO MALAYSIAN NARRATIVES: LOCALES IN THE GARDEN OF EVENING MISTS AND THE NIGHT TIGER
}

\author{
Swagata Sinha Roy ${ }^{1} \&$ Kavitha Subaramaniam ${ }^{2}$ \\ 1,2Universiti Tunku Abdul Rahman, Universiti Tunku Abdul Rahman \\ (swagata@utar.edu.my, kavitha@utar.edu.my)
}

\begin{abstract}
If one has not read local English novels like The Garden of Evening Mists and The Night Tiger, one would never be able to imagine the wonders of locales depicted in these two books. One of the reasons the authors here want to visit a said destination is because of the way a certain place is pictured in narratives. Tan Twan Eng brings to life the beauty of Japanese gardens in Cameron Highlands, in the backdrop of postWorld War II while Yangsze Choo takes us into several small towns of Kinta Valley in the state of Perak in her beautifully woven tale of the superstitions and beliefs of the local people in Chinese folklore and myth in war torn Malaysia in the 1930s and after. Many of the places mentioned in these two novels should be considered places to visit by tourists local and international. Although these Malaysian novelists live away from Malaysia, they are clearly ambassadors of the Malaysian cultural and regional heritage. In this paper, a few of the places in the novel will be looked at as potential spots for the coming decade. The research questions considered here are i) what can be done to make written narratives the new trend to pave the way for Visit Malaysia destinations? ii) how could these narratives be promoted as guides to the history and culture of Malaysia? The significant destinations and the relevant cultural history of the regions will be discussed in-depth to come to a relevant conclusion.
\end{abstract}

KEYWORDS: The Garden of Evening Mists, The Night Tiger, tourist destinations, Cameron Highlands, Kinta Valley

\section{PURPOSE AND BACKGROUND}

When one speaks of 'tourism' what generally comes to one's mind? If one is a regular tourist, it would be tours to take at a certain place, and most likely, the oft-visited popular localities and touristy landmarks. For the traveler perhaps, it would go deeper as travelers may avoid the regular tourist spots and prefer to go beyond. Here we would like to look further at readers perhaps. What would readers go in for when they go on a tour?

More often than not, readers would love to check out places mentioned in novels they have read so why not consider narratives as a new form of travel and tourism? It is known that scenes in celluloid have attracted people to go visit certain places and these have been proved through tours such as Sound of Music Salzburg tour and Lord of the Rings tour from Auckland to Queenstown.

If such tours can happen in foreign locales, this can be made available in Malaysia too. Actually, there are several novels in the various languages used in the country that one can consider as the locations for travelling but here we would like to look at two novels by Malaysian authors, namely The Night Tiger by Yangsze Choo and the Garden of Evening Mists by Tan Twan Eng. This kind of tourism is suggested as an exciting alternative to visiting certain lesser known or less highlighted places which are of historical significance. 


\section{METHODOLOGY}

For the purpose of this paper, a textual analysis has been employed to wean all the locations of interest from the novels in question. At close reading the locations provide the reader and the travel planner a whole host of places the local as well as the international (ASEAN, Asian, Arab, African, European and American) tourists may find worthy of visiting, especially via various travel modes such as trains, buses and cars.

\section{FINDINGS}

\section{Of Folklore and Fact in The Night Tiger}

A cursory reading of this novel, one gets to travel to various places in the Kinta Valley, namely Ipoh and Batu Gajah. Historically, this is set during 1930s when Malaya was occupied by colonial forces and the narrative flows into the 1970s. Basically, there is mystery at the start of the novel. In summary, this story has alternated frameworks and the lead characters are Ren, an 11-year-old 'servant' boy who is on a mission to locate his master's (now dead) dislocated finger.

He meets Ji Lin, the voice through which we are immersed in the story, and who is a dressmaker by day, moonlighting as a dancehall girl for supplementary income to enable her to settle her mother's Mahjong debts. Ji Lin helps recover the missing finger while she works as an assistant at the Batu Gajah hospital. All the characters in the novel are strangely bound to each other and their destinies merge.

What is amazing about this story is the belief in spirits and weretigers, which is similar to the concept of werewolves in western folklore. This folklore can be built into tourist brochures to enable visitors to the Kinta Valley have some background information on both Malaysia and the beliefs and superstitions such as the idea of weretigers, also seen as shapeshifters as these entities could turn from man to beast and also the Chinese belief in the elements or fengshui.

The five significant characters in the novel correspond to the five virtues in Confucianism, which according to author Choo Yangsze, comprise benevolence, honesty, knowledge, integrity and proper behaviour. These virtues could be something that tourists can learn about.

The belief that the separated finger needs to be reunited with the body within a said number of days so that Ren's master's soul can rest in peace is also mentioned over and over. There are endless learning points in the novel which can interest people from different towns and cities within Malaysia itself.

Fictionalised Ipoh is where part of the story takes place and we get glimpses, peeks into Kamunting, a detailed look at the Batu Gajah train stations, hospital and the Kinta river. Many events and places were also drawn from the writer's imagination but the way the writer describes the bylanes and roads between certain houses in various places in the novel could also be capitalised on for tourism purposes.

\section{Of Memories and Mists in The Garden of Evening Mists}

Another novel that could help promote certain places in Malaysia as must-visit spots can be found in Tan Twan Eng's The Garden of Evening Mists. Now residing in South Africa, Tan has given a beautiful description of the Cameron Highlands in his second novel.

Here, the story is told in a series of flashbacks taking the reader to various locations within the highlands, the most remarkable being a place called 'Yugiri' which is always bathed in mists in the evening. In the 
novel, which has been adapted into celluloid, the kind of Japanese garden mentioned had to be created for the film shooting and that itself can be a tourist draw.

The novel, which won the 2012 Man Asian Literary prize tells the haunting heart-breaking tale of Yun Ling, who, along with her sister Hong, were at a Japanese prison camp where they experienced all sorts of atrocities. Yun Ling who survives and goes on to be a judge, goes back in time on her retirement and relates the story of her life and her interest in 'constructing' a Japanese garden in her sister's memory.

In the process of setting up the garden, Yun Ling falls in love with the former gardener of the Japanese emperor, Nakamura Aritomo and gets to realise her dream of building the garden as a memorial for not only her sister but also for her lover.

This novel spans the time of World War II, the 1950s as well as the 1980s when the novel opens. It is a tragic tale of the horrors of war and the realization and acceptance of life's challenging struggles, while aligning with the philosophy of the construction of Japanese gardens. The fact that most of the scenes take place in various spots in the Cameron Highlands can actually be a tourist draw, The novel also includes characters from various nationalities which can make a tourist or traveler interested in the history of the highlands,

Also the evocative scenes where the weather, the mood and the flora and fauna come alive are also points that can be emphasized in a tourist brochure, Location wise apart from the tea plantations and the Mossey forest of the Cameron Highlands, there were also other places reconstructed here especially for the film shooting and these include Carey Island, Temoh Resort and Sungai Lembing mines - locations which can be added as travel destinations for the interested

\section{CONCLUSION}

The two novels, The Night Tiger and The Garden of Evening Mists can be seen as two narratives that can pave the way for more local fictional writings to be used in the concept of 'book trails' and 'story treks' as a part of promoting reading as well as travel to Malaysians and foreigners.

These novels help take one back to various moments in time as well as different historical epochs, further heightened by the beauty of the descriptions of the places as well as local beliefs, customs and practices that can be gleamed from a quick reading of the narratives.

\section{CONTRIBUTION/PRACTICAL IMPLICATIONS}

More and more innovative ways can be suggested to help boost the tourism industry in Malaysia, especially now that the pandemic has affected all manner of travelling. The researchers suggest that one way can be by introducing written narratives where stories take place in believable and often 'real' places and those places be promoted as they have found their way into the stories, whether portraying the back alleys of a narrow housing colony, or a war torn prison camp sites, misty tea gardens, eateries in urban settings or even certain 'dance halls' these could be the next tourism trend.

More so, with the advent of Virtual reality and Augmented reality which are being made use of for promoting virtual tours at the click of a button in many destinations around the world, this could be the next big thing in local tourism for both local and international visitors. 


\section{REFERENCES}

Choo, Yangsze. (2019). The Night Tiger. London: Quercu. https://www.thebooktrail.com/authorsonlocation/ malaya-with-the-night-tiger-and-yangsze-choo/

Tan Twan Eng. (2019). The Garden of evening mists. Edinburgh: Canongate. https://www.japantimes.co.jp/ culture/2020/07/04/books/book-reviews/the-garden-of-evening-mists/ 